\title{
First Record of Cleantioides planicauda (Crustacea: Isopoda: Holognathidae) from South Korea
}

\author{
Ji-Hun Song ${ }^{1}$, Min-Seop Kim ${ }^{1,2}$, Gi-Sik Min ${ }^{1, *}$ \\ 'Department of Biological Sciences, Inha University, Incheon 402-751, Korea \\ ${ }^{2}$ Marine Biodiversity Institute of Korea, Seocheon 325-902, Korea
}

\begin{abstract}
Cleantioides planicauda (Benedict, 1899) has previously been recorded in China and Japan. In the present study, to our knowledge, we report for the first time the occurrence of this species in South Korea. Here, we provide detailed descriptions and illustrations of the diagnostic characteristics of $C$. planicauda. Further, for the first time, we determined the partial sequence of mitochondrial cytochrome $c$ oxidase subunit $1(\mathrm{CO})$ gene of $C$. planicauda for molecular characteristic. Additionally, we provide a key to the Korean species and distribution of the genus Cleantioides. As a result of this study, four species of the genus Cleantioides, including C. planicauda, have now been recorded in South Korea.
\end{abstract}

Keywords: Cleantioides planicauda, CO1, distribution, Holognathidae, Isopoda, South Korea

\section{INTRODUCTION}

The genus Cleantioides Kensley and Kaufman, 1978 (Crustacea: Malacostraca: Isopoda), is one of among five genera belonging to the family Holognathidae Thomson, 1904 that is currently composed of 13 species. Three species of Cleantioides: C. japonica (Richardson, 1912), C. emarginata Kwon and Kim, 1992, and C. poorei Kwon and Kim, 1992, have previously been recorded in South Korea, while Cleantioides planicauda (Benedict, 1899) has previously been recorded in China and Japan (Richardson, 1912; Kwon and Kim, 1992; Liu et al., 2008; Liu and Poore, 2013). In the present study, we report for the first time the occurrence of $C$. planicauda in South Korea.

The genus Cleantioides are distinguished by the following characteristics: 1) the cylindrical body; 2) pleonite 1 free and articulating; 3) pleotelson rounded, ending with an oblique plane; 4) antenna 1 flagellum a minute article, distinctly smaller than peduncle article $3 ; 5$ ) antenna 2 flagellum with a single clavate article; 6 ) dactylus of pereopod 4 reduced to unguis alone; and 7) uniramous uropod (Poore and Lew Ton, 1990; Kwon and Kim, 1992).
Here, we provide detailed descriptions and illustrations of the diagnostic characteristics of $C$. planicauda. Further, we determined the partial sequence of the mitochondrial cytochrome $c$ oxidase subunit 1 ( $\mathrm{CO} 1)$ gene of $C$. planicauda for molecular characteristic. Additionally, we provided a key to the Korean species and distribution of the genus Cleantioides (Fig. 1). As a result of this study, four species of the genus Cleantioides, including C. planicauda, have now been recorded in South Korea.

\section{MATERIALS AND METHODS}

\section{Sample collection and morphological analysis}

All of the specimens examined in the present study, were collected by light trap from the Geumodo Island $\left(34^{\circ} 30^{\prime} \mathrm{N}, 127^{\circ}\right.$ $45^{\prime} \mathrm{E}$ ) in South Korea. They were preserved directly in $95 \%$ ethyl alcohol after collection. All of the examined specimens were deposited in the National Institute of Biological Resources (NIBR) and Inha University, South Korea.

The specimens were dissected and examined under a stereomicroscope (Model SZX-7; Olympus, Tokyo, Japan). Illus-

\footnotetext{
(c) This is an Open Access article distributed under the terms of the Creative Commons Attribution Non-Commercial License (http://creativecommons.org/ licenses/by-nc/3.0/) which permits unrestricted non-commercial use, distribution, and reproduction in any medium, provided the original work is properly cited.

pISSN 2234-6953 eISSN 2234-8190

*To whom correspondence should be addressed

Tel: 82-32-860-7692, Fax: 82-32-874-6737

E-mail: mingisik@inha.ac.kr 


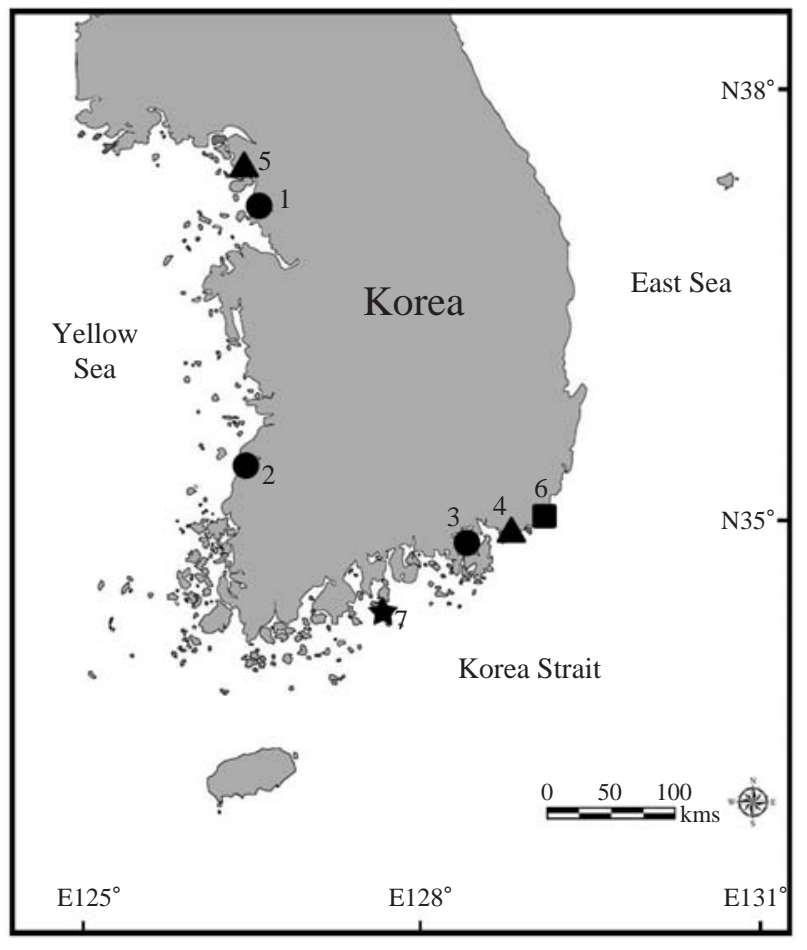

Fig. 1. Distribution of genus Cleantioides from South Korea based on previous records and on the present study. C. japonica $(\bullet$ ): 1, Incheon-si, Sorae; 2, Gochang-gun, Pyunggok; 3, Geojesi, Isl. Geojedo, Changho-ri. C. emarginata (4): 4, Busan, Myungji-dong; 5, Ganghwa-gun, Choji-ri. C. poorei ( $)$ ): 6, Busan, off Mipo. C. planicauda ( $\star$ ): 7, Yeosu-si, Isl. Geumodo, Hakdong.

trations of appendages were made with a drawing tube connected to a light microscope (Model DM 2500, X50-630; Leica, Wetzlar, Germany). Figure of the whole body was made using a drawing tube attached to a stereomicroscope (Olympus SZX-12). Measurements of the whole body length and appendages were done with a stage micrometer (Leica, Heidelberger, Germany) and an ocular micrometer.

\section{DNA sequence determination}

The genomic DNA of the specimens was extracted from the appendages by using a DNeasy Blood and Tissue Kit (Qiagen, Valencia, CA, USA) according to the manufacturer's instructions. The target DNA fragment of the $\mathrm{CO}$ gene was amplified by the polymerase chain reaction (PCR) with the following primers: LCO1490 5'-GGTCAACAAATCATAAAGA TATTGG-3' and HCO2198 5'-TAAACTTCAGGGTGACC AAAAAATCA-3' (Folmer et al., 1994). PCR amplification was carried out under the following conditions: $94^{\circ} \mathrm{C}$ for 3 min, 35 cycles of $95^{\circ} \mathrm{C}$ for $15 \mathrm{sec}, 42^{\circ} \mathrm{C}$ for $30 \mathrm{sec}$, and $72^{\circ} \mathrm{C}$ for $1 \mathrm{~min}$, with a final extension step at $72^{\circ} \mathrm{C}$ for $7 \mathrm{~min}$. All PCR products were purified with the QIAquick PCR purification Kit (Qiagen), and sequenced with an automated sequencer ABI 3100 (PerkinElmer, Foster City, CA, USA).

\section{SYSTEMATIC ACCOUNTS}

Order Isopoda Latreille, 1817

Suborder Valvifera Sars, 1882

1*Family Holognathidae Thomson, 1904

Genus Cleantioides Kensley and Kaufman, 1978

${ }^{2 *}$ Cleantioides planicauda (Benedict, 1899) (Figs. 2-4)

Cleantis planicauda Benedict, 1899: 851; Richardson, 1905: 404, figs. 452-454; Menzies and Frankenberg, 1966: 23; Schultz, 1969: 82, fig. 105; Brusca and Wallerstein, 1979a: 266; 1979b: 90.

Cleantioides planicauda Kensley and Kaufman, 1978: 661; Brusca and Iverson, 1985: 58, fig. 17; Liu et al., 2008: 1; Liu and Poore, 2013: 625.

Material examined. Korea: $5 \diamond^{\nearrow} \varnothing^{\nearrow}$, Jeollanam-do, Yeosu-si, Isl. Geumodo, $34^{\circ} 30^{\prime} \mathrm{N}, 127^{\circ} 45^{\prime} \mathrm{E}, 3 \mathrm{Jul} 2013$, by Light Trap, depth 3-4 m, collected by Hong SS.

Description. Male: Body elongate, cylindrical, about 10.7 $\mathrm{mm}$, parallel-sided, almost 5.1 times longer than greatest width. Head approximately 1.6 times wider than long; anterior margin emarginated at midpoint; posterior margin convex. Eyes situated near antero-lateral angle of head. Coxal plates small and hardly visible dorsally on pereonites $2-4$, but distinctly visible dorsally on pereonites 5-7. Pleonites composed of 4 segments (1-3 complete, 4 incomplete). Pleotelson parallel-sided with rounded apex; dorsum of distal half with slightly oblique plane with slightly bilobed depression (Fig. 2A, B).

Antenna 1 (Fig. 2C) short, composed of 4 articles; reaching to end of article 2 of antenna 2 peduncle; fourth article being the single flagellar article with 8 apical aesthetascs. Antenna 2 (Fig. 2D) composed of 6 articles; first article very short and almost immobile; second article very stout; articles 3-5 having almost similar lengths; sixth article being the single clavate article with many short fine setae and relatively long distal setae.

Mandible (Fig. 2E) lacking palp; incisor with 4-5 cusps; spine row of about 8 dentate spines; molar process stout. Maxilla 1 (Fig. 2F) endopod with 3 stout plumose setae apically; exopod with 8-9 serrate spines. Maxilla 2 (Fig. 2G) composed of 3 lobes; inner lobe with 8 plumose setae later- 


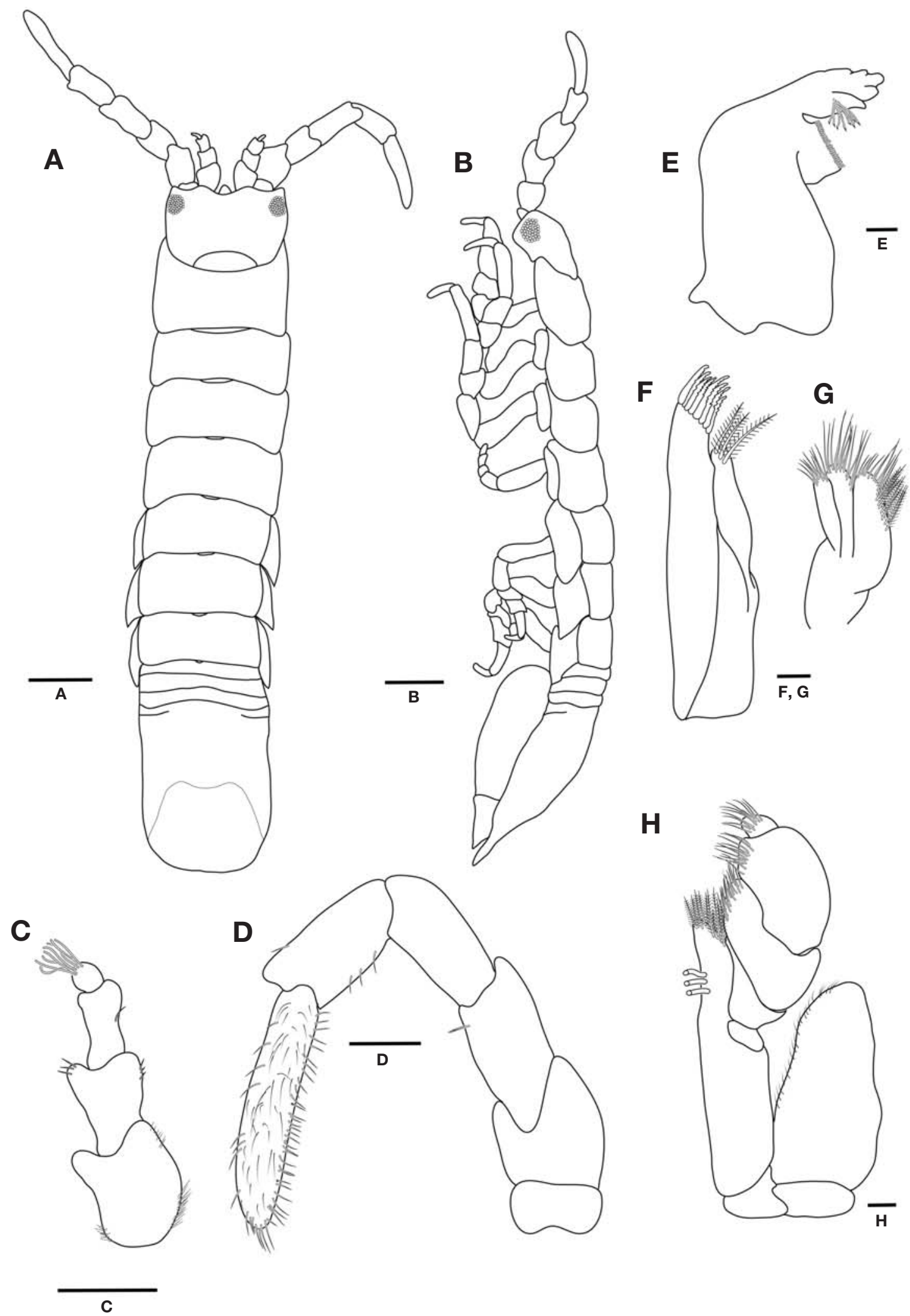

Fig. 2. Cleantioides planicauda, male. $A$, Body, dorsal view; B, Body, lateral view; $C$, Antenna 1 ; $D$, Antenna 2; E, Mandible; F, Maxilla 1; G, Maxilla 2; $H$, Maxilliped. Scale bars: $A, B=1 \mathrm{~mm}, C, D=0.2 \mathrm{~mm}, E-H=0.1 \mathrm{~mm}$. 


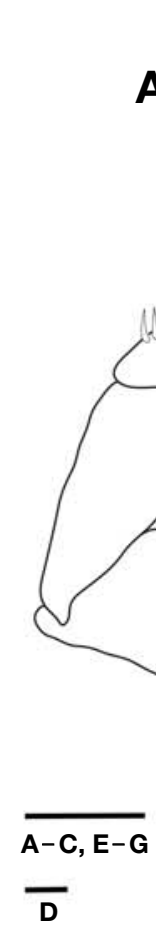

A

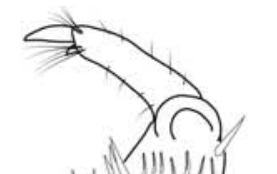

(1) 1 III)

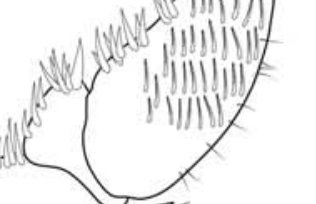

B

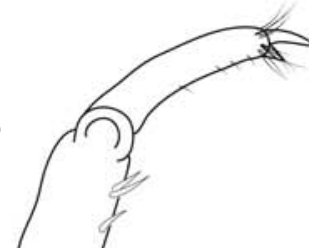

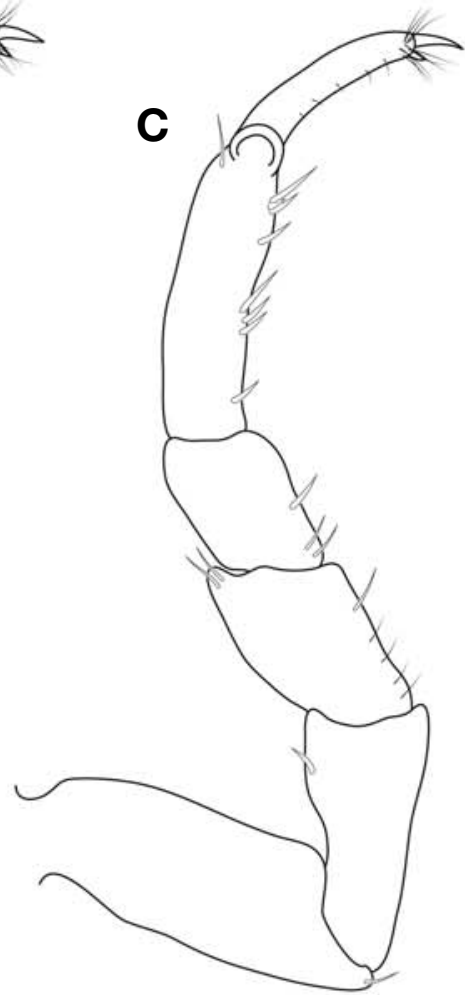

D

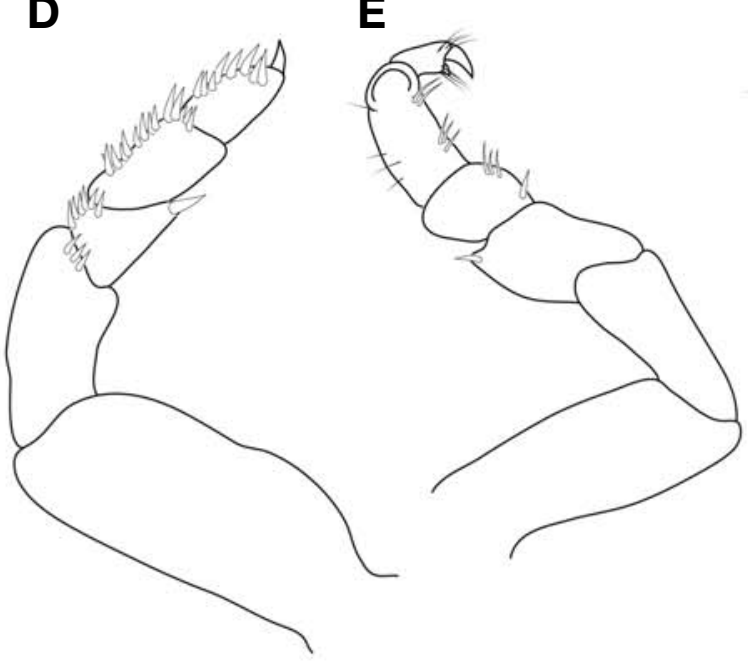

$\mathbf{F}$

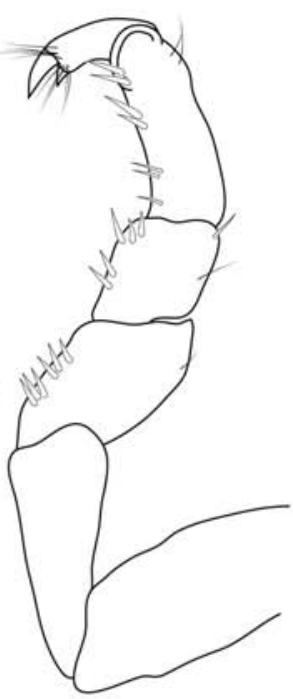

G

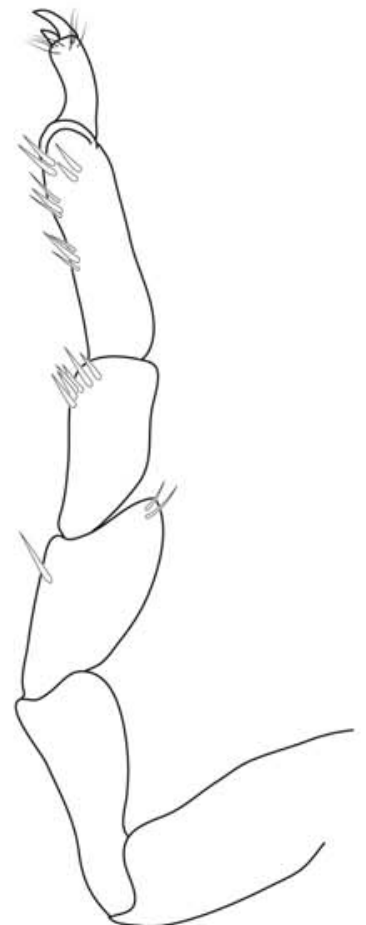

Fig. 3. Cleantioides planicauda, male. A, Pereopod 1; B, Pereopod 2; C, Pereopod 3; D, Pereopod 4; E, Pereopod 5; F, Pereopod 6; G, Pereopod 7. Scale bars: $A-C, E-G=0.2 \mathrm{~mm}, D=0.1 \mathrm{~mm}$. 
A

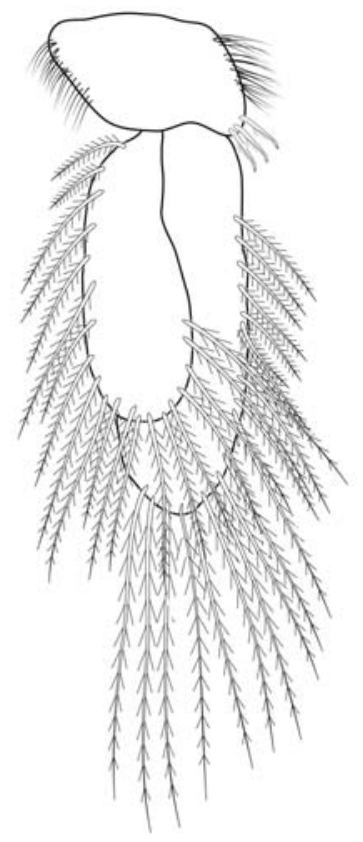

\footnotetext{
D
}

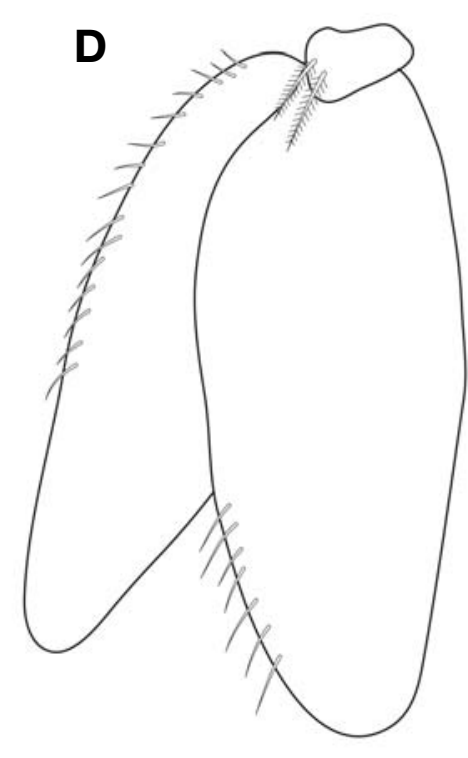

B

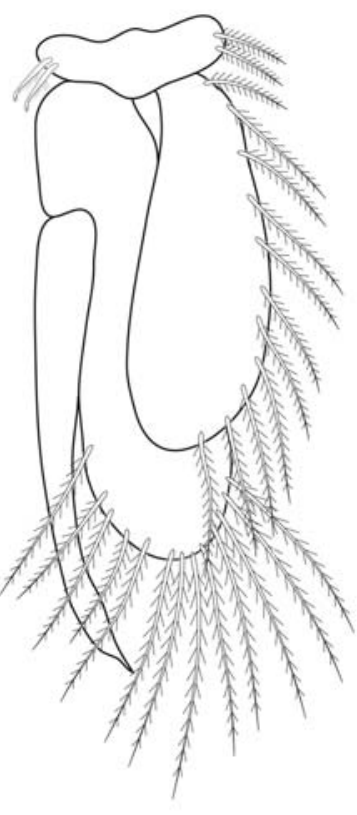

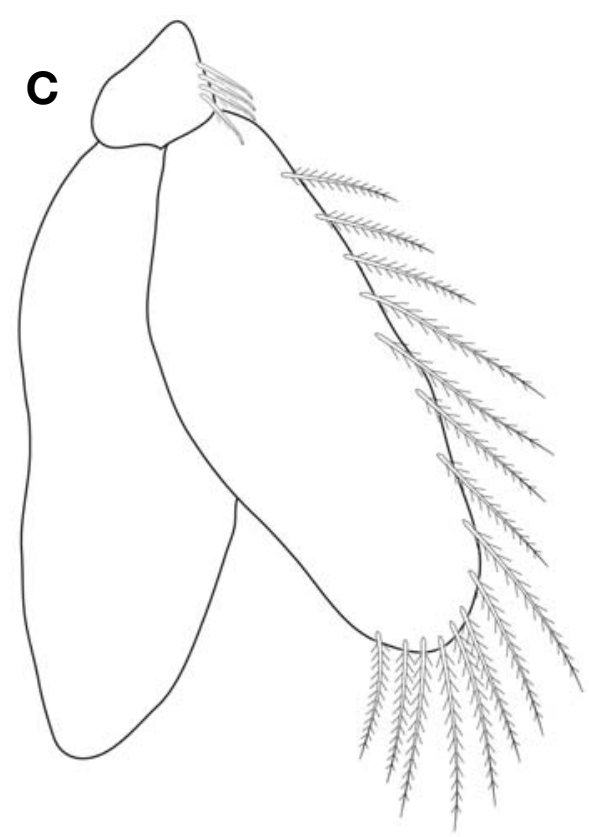

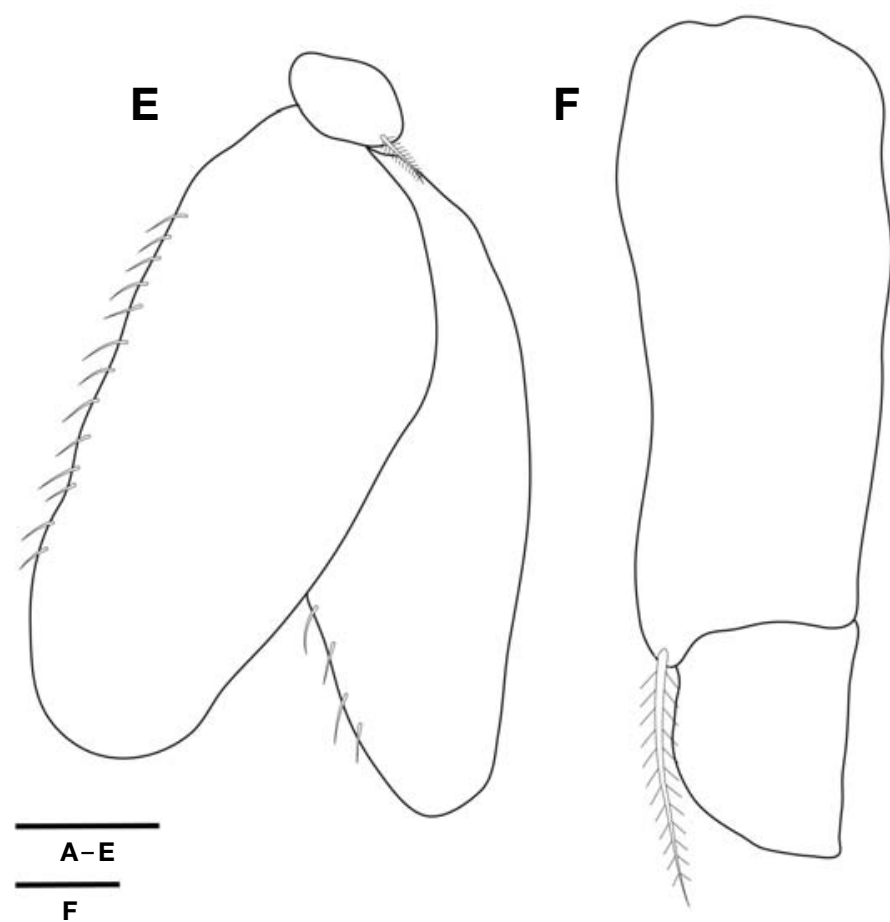

Fig. 4. Cleantioides planicauda, male. A, Right pleopod 1; B, Left pleopod 2; C, Right pleopod 3; D, Right pleopod 4; E, Left pleopod 5; F, Uropod. Scale bars: $A-F=0.2 \mathrm{~mm}$.

ally and 10 simple setae apically; inner portion of outer lobe with 13-15 simple setae, outer portion with 9-11 setae. Maxilliped (Fig. 2H) palp composed of 5 articles; four distal articles setose; endite with 3 coupling hooks and $10-11$ plumose setae distally.
Pereopod 1 (Fig. 3A) stout; merus with 6-7 posterodistal and anterodistal spines; carpus with 9 spines on posterior margin; propodus expanded with 4 clusters of 11 spines on posterior margin with 33-35 serrulate setae on mesial surface; dactylus unguis stout. Pereopods 2 and 3 (Fig. 3B, C) 
similar, longer than first pereopod; ischium with 1-2 spines; merus with 6 spines, 3 spines and 4 simple setae, respectively; carpus with 3 spines on posterior margin; propodus with 9 spines on posterior margin, 1 spine on anterior margin and 8 spines on posterior margin, respectively; dactylus unguis slender. Pereopod 4 (Fig. 3D) greatly reduced and short; ischium with 3 posterodistal spines; merus with 6 spines on posterior margin and one stout spine on anterodistal margin; carpus with 14 spines on posterior margin; propodus with 8 spines on posterior margin; dactylus reduced to single compact unguis only. Pereopods 5-7 (Fig. 3E-G) increasing in length posteriorly; pereopod 5 , merus with 1 spine on anterior margin; carpus with 4 spines on posterior margin; propodus with 5 spines on posterior margin and 4 setae on anterior margin; dactylus hook-shaped, with stout unguis; pereopod 6 , merus with 6 spines on posterior margin and 1 setae on anterior margin; carpus with 5 spines on posterior margin and 1 spine, 1 seta on anterior margin; propodus with 7 spines on posterior margin and 2 setae on anterior margin; dactylus hook-shaped, with stout unguis; pereopod 7, merus with 1 spine on posterior margin and 2 spines on anterior margin; carpus with 6 spines on posterior margin; propodus with 8 spines on posterior margin and 2 spines on mesial surface; dactylus hook-shaped, with stout unguis.

Pleopod 1 (Fig. 4A), sympod with 3 retinacula and fine setae; exopod shorter than endopod, both with numerous plumose setae marginally. Pleopod 2 (Fig. 4B), sympod with 2 retinaculae and 2 plumose setae; both rami with plumose marginal setae; appendix masculine arising from the median margin of the endopod, tapering to acute apex surpassing to distal margin of endopod. Pleopod 3 (Fig. 4C), sympod having 4 retinaculae; both rami subequal in length; exopod with marginal plumose setae, endopod lacking plumose setae. Pleopod 4 (Fig. 4D), sympod small with 2 plumose setae; both rami subequal in length with some simple marginal setae. Pleopod 5 (Fig. 4E), sympod with 1 plumose seta; both rami similar to those of pleopod 4. Uropods (Fig. 4F) uniramous with single long plumose seta proximally; apically truncate.

Habitat. Habitat information from the type locality is not known. This species collected from the South Korea on sandy and gravel bottom with some green algae at 3-4 $\mathrm{m}$ depth.

\section{Key to the Korean species of the genus Cleantioides}

1. The posterior plane of pleotelson has a median tubercle . C. japonica (Richardson, 1912)

- The posterior plane of pleotelson unarmed (no tubercle)

2. Posterior margin of pleotelson with emarginated apex $\ldots$. C. emarginata Kwon and Kim, 1992
- Posterior margin of pleotelson with rounded apex $\cdots \cdots \cdots 3$

3 . Body almost 4 times longer than greatest width; coxal plates visible dorsally on pereonites $2-7 \quad \ldots \ldots \ldots \ldots \ldots \ldots \ldots$. C. poorei Kwon and Kim, 1992

- Body almost 5.1 times longer than greatest width; coxal

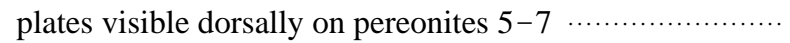
C. planicauda (Benedict, 1899)

Remarks. Cleantis planicauda was first described by Benedict (1899) based on specimens collected from Florida, USA. Later, Kensley and Kaufman (1978) transferred this species to the genus Cleantioides, because of its unique characteristics, especially the existence of a uropodal endopod (in the genus Cleantioides, the uropod lack an endopodal ramus on the inner face). Cleantioides planicauda has previously been reported in Florida, USA; Southern Mexico to Georgia, USA; the Caribbean Sea; South Eastern Brazil; the Eastern China Sea (Benedict, 1899; Richardson, 1905; Schultz, 1969; Brusca and Iverson, 1985; Liu and Poore, 2013); and the Sea of Japan (The East Sea) (Liu et al., 2008).

Cleantioides planicauda is distinguished from other Korean species by several characters listed in the key. Cleantioides poorei Kwon and Kim, 1992 is very similar to C. planicauda regarding the following: 1) planiform region of the pleotelson with anteriorly bilobed depression (more distinct in $C$. poorei); and 2) the shape of the head (anterior margin emarginated at midpoint). However, C. planicauda differs from $C$. poorei in having longer antenna 2; much slender pereopod 7; narrower body (5.1 times longer than the greatest width in C. planicauda versus 4 times in $C$. poorei); the number of dorsally visible coxal plates (visible dorsally on pereonites 5-7 in C. planicauda versus on pereonites 2-7 in C. poorei); and suture of maxillipedal palp between 2 and 3 (complete suture in C. planicauda versus partial suture in C. poorei).

In general, Cleantioides planicauda from the South Korea agrees well with the original description of Benedict (1899) and the illustrations of Richardson (1905). We determined the partial $\mathrm{COl}$ sequence of $C$. planicauda and registered the sequence at GenBank (accession numbers: KJ149447KJ149451). As a result of this study, world distribution of $C$. planicauda is more widened, and provides additional information of genus Cleantioides in South Korea.

\section{ACKNOWLEDGMENTS}

This work was supported by the grants of Inha University and the National Institute of Biological Resources (NIBR), funded by the Ministry of Environment (MOE) of the Republic of Korea (NIBR NO. 2013-02-001). 


\section{REFERENCES}

Benedict JE, 1899. [Description of Cleantis planicauda] In: Key to the isopods of the Pacific coast of North America, with descriptions of twenty-two new species (Ed., Richardson H). Proceedings of The United States National Museum, 21:851852.

Brusca RC, Iverson EW, 1985. A guide to the marine isopod Crustacea of Pacific Costa Rica. Revista de Biología Tropical, 33:1-77.

Brusca RC, Wallerstein BR, 1979a. The marine isopod crustaceans of the Gulf of California. II. Idoteidae. New genus, new species, new records and comments on the morphology, taxonomy and evolution within the family. Proceedings of the Biological Society of Washington, 92:253-271.

Brusca RC, Wallerstein BR, 1979b. Zoogeographic patterns of idoteid isopods in the northeast Pacific, with a review of shallow-water zoogeography for the region. Bulletin of the Biological Society of Washington, 3:67-105.

Folmer O, Black M, Hoeh W, Lutz R, Vrijenhoek R, 1994. DNA primers for amplification of mitochondrial cytochrome $c$ oxidase subunit I from diverse metazoan invertebrates. Molecular Marine Biology and Biotechnology, 3:294-299.

Kensley B, Kaufman HW, 1978. Cleantioides, a new idoteid isopod genus from Baja California and Panama. Proceedings of the Biological Society of Washington, 91:658-665.

Kwon DH, Kim HS, 1992. Two new species of the genus Cleantioides (Isopoda: Valvifera: Holognathidae) from Korea. Korean Journal of Systematic Zoology, Special Issue, 3:85-
92.

Liu W, Poore GCB, 2013. A new record of Cleantioides emarginata Kwon and Kim, 1992 (Crustacea, Isopoda, Valvifera) from Changjiang River estuary, China. Chinese Journal of Oceanology and Limnology, 31:625-631.

Liu W, Poore GCB, Lu J, 2008. Cleantioides longicornis, a new species of Holognathidae (Crustacea, Isopoda, Valvifera) in the Yangtze Estuary, China[OL] [Internet]. Sciencepaper Online, Beijing, Accessed 22 Nov 2013, <http://www.paper. edu.cn/en_releasepaper/content/24166>.

Menzies RJ, Frankenberg D, 1966. Handbook on the common marine isopod Crustacea of Georgia. University of Georgia Press, Athens, pp. 1-93.

Poore GCB, Lew Ton HM, 1990. The Holognathidae (Crustaea : Isopoda : Valvifera) expanded and redefined on the basis of body-plan. Invertebrate Systematics, 4:55-80.

Richardson H, 1905. Monographs on the Isopods of North America. Bulletin of the United States National Museum, 54:1-727.

Richardson H, 1912. Description of a new species of isopod of the genus Cleantis from Japan. Proceedings of The United States National Museum, 42:27-29.

Schultz GA, 1969. How to know the marine isopod crustaceans. W. C. Brown, Dubuque, Iowa, pp. 1-359.

Received November 4, 2013 Revised January 16, 2014 Accepted January 17, 2014 